\title{
STRATEGIC FOOD CONSUMPTION PATTERNS OF HOUSEHOLD IN INDONESIA
}

\author{
Sa'diyah Ana Arifatus ${ }^{1,2 \star}$, Anindita Ratya ${ }^{3}$, Hanani Nuhfil $^{3}$, Muhaimin Abdul Wahib $^{2}$ \\ ${ }^{1}$ Department of Agribusiness, University of Tribhuwana Tunggadewi, Malang, Indonesia \\ ${ }^{2}$ Doctoral Program, University of Brawijaya, Malang, Indonesia \\ ${ }^{3}$ Department of Socio-Economics, University of Brawijaya, Malang, Indonesia \\ ${ }^{\star}$ E-mail: ana.arifatus@unitri.ac.id
}

\begin{abstract}
In order to fulfill food, a study of food patterns is needed. Food consumption patterns of a household will change over time, and differ from region to region. Changes in consumption patterns over time are influenced by income changes, changes in people's awareness of food and nutrition, and lifestyle changes. The purpose of this research is to analyze: household food consumption pattern; the pattern of changes in food prices; and share of consumer expenditure on each food (rice, corn, shallot, chili, beef, and sugar). This study uses SUSENAS secondary data from 2011-2016. Data analysis with a descriptive quantitative method resulted in the conclusion: between 2011-2016 the average consumption of rice in urban areas is smaller than in rural areas. Conversely, consumption of beef in urban areas is greater than in rural areas, chili and shallot commodity prices are the most volatile commodity prices, the largest proportion of household food expenditure in Indonesia is for rice commodities, both in urban and rural areas. The results of this analysis have implications for the households to maintain the consumption pattern, especially to diversify the consumption of rice with other staple food.
\end{abstract}

\section{KEY WORDS}

Food consumption, food price, strategic commodity, consumption pattern.

Foods that include rice, corn, soybeans, beef, shallot, chili, and sugar are the basic necessities for human life (Agriculture Department, 2014). According to (Amang, 1995) and (Simatupang, 2012), corn, soybeans, and sugar are strategic commodities that are crucial to achieving the main goals of agricultural development: the dynamism of the village economy, strengthen food security, and reduce poverty and improve the economic welfare of the population. In addition, the four commodities are mainly soybean and sugar are vulnerable to international market turmoil. Therefore, these four commodities become "Special Product" for Indonesia. The importance of food according to the Agriculture Department (2014) is also indicated by the government's policy focus for 2015 - 2017 is to realize rice, corn and soybean self-sufficiency. Then followed by efforts to realize self-sufficiency of beef, sugar, shallot, and chili as a national staple.

Food is an important topic to study. Food is the most basic human needs and fulfillment is part of human rights guaranteed by the 1945 Indonesian Constitution. The fulfillment of individual food sufficiency is the essence of food security. Next thing to note in order to fulfill the adequacy of food is the consumption pattern. Household food consumption patterns will change over time, food consumption patterns will also differ from region to region. Changes in consumption patterns over time are influenced by income changes, changes in people's awareness of food and nutrition, and lifestyle changes (Samuelson \& Nordhaus, 2004).

According to (Thiele \& Weiss, 2003), and (Ogundari \& Arifalo, 2013) there are differences in food consumption patterns between urban households and rural households. This condition led to different levels of diversification of household food in Indonesia. This difference is also accompanied by differences in income levels and food prices. Therefore, it is necessary to know the pattern of household food consumption of Indonesia, through the pattern of food expenditure allocation and the pattern of changes in food demand.

The purpose of this research is to analyze: (1) The pattern of the household for strategic food consumption; (2) The pattern of changes in strategic food prices; and (3) 
Share of consumer expenditure on each strategic food (rice, corn, beef, chili, shallot, and sugar).

\section{METHODS OF RESEARCH}

The study used secondary data in the form of raw data of SUSENAS (National Socioeconomic Survey) in 2011-2016. The SUSENAS data used included: total household expenditure, total household food expenditure, quantity and total strategic food expenditure (rice, corn, beef, shallots, chilies, and sugar), as well as the type of area where the household lives.

Food commodities in this study include rice, corn, beef, chili, shallot, and sugar. These 6 foodstuffs are Indonesia's strategic commodities. Descriptive analysis is used to look at household consumption patterns, and patterns of price changes, and the proportion of public spending on strategic commodities. Analysis of household preferences for strategic food consumption is calculated using the following formula:

$$
\mathrm{w}_{\mathrm{i}}=\frac{\mathrm{b}_{\mathrm{i}}}{\mathrm{x}} \times 100 \%=\frac{\mathrm{p}_{\mathrm{i}} \cdot \mathrm{q}_{\mathrm{i}}}{\sum \mathrm{p}_{\mathrm{i}} \cdot \mathrm{q}_{\mathrm{i}}} \times 100 \%
$$

Where: $\mathrm{i}=1,2, \ldots, 6 ; \mathrm{i}=1$ (rice), 2 (corn), 3 (beef), 4 (shallot), 5 (chili), 6 (sugar); $w_{i}=$ Proportion of commodity expenditure $\mathrm{i}(\%) ; b_{i}=$ Commodity expenditure $\mathrm{i}(\mathrm{Rp}) ; x=$ Total expenditure from strategic food $(\mathrm{Rp}) ; p_{i}=$ price of commodity $\mathrm{i}(\mathrm{Rp}) ; q_{i}=$ quantity of commodity purchases $(\mathrm{kg})$.

\section{RESULTS AND DISCUSSION}

The Pattern of Household for Strategic Food Consumption. The success of the development of a nation is determined by the availability of qualified human resources (HR) quality, namely human resources that have a strong physical, strong mental, excellent health, and smart. This condition can be achieved if followed by adequate food intake (Bappenas, 2007).

Figures 1 and 2 shows that rice consumption in rural areas from 2011 to 2016 is always higher than in urban areas. This is because rural household income is lower than urban household income. Furthermore, Engel stated that the poorer the household, the more the proportion of income spent to meet food needs (Bourguignon \& Chakravarty, 2003). Rice commodities have the largest expenditure compared to other food commodities. This shows the pattern of food consumption Furthermore in Indonesia is still dominated by high carbohydrates, especially rice as staple food. The same thing was put forward by (Jamal, Ariningsih, Hendiarto, Noekman, \& Askin, 2016) that the average quality of food consumption in Indonesia is still low and less diversified, still dominated by carbohydrate food sources, especially from the grains.

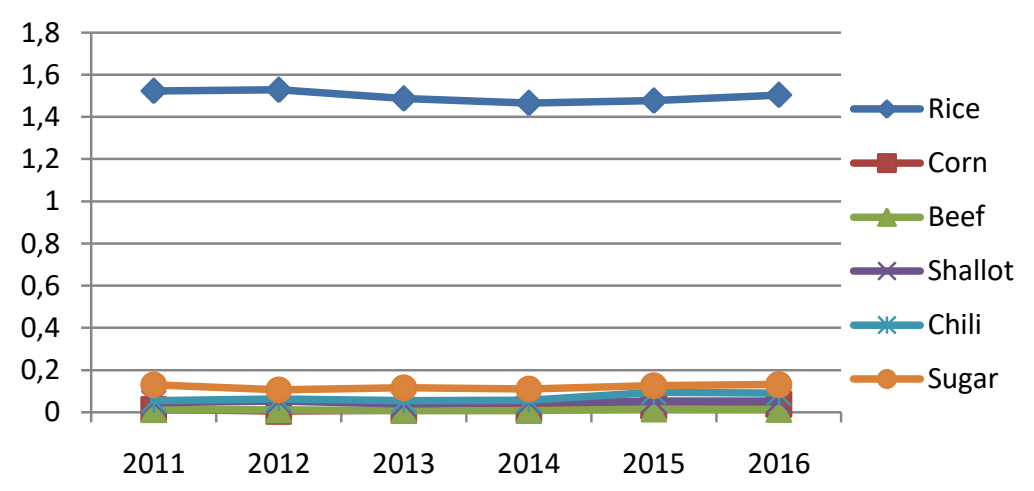

Figure 1 - Household Food Consumption in Urban, 2011-2016 


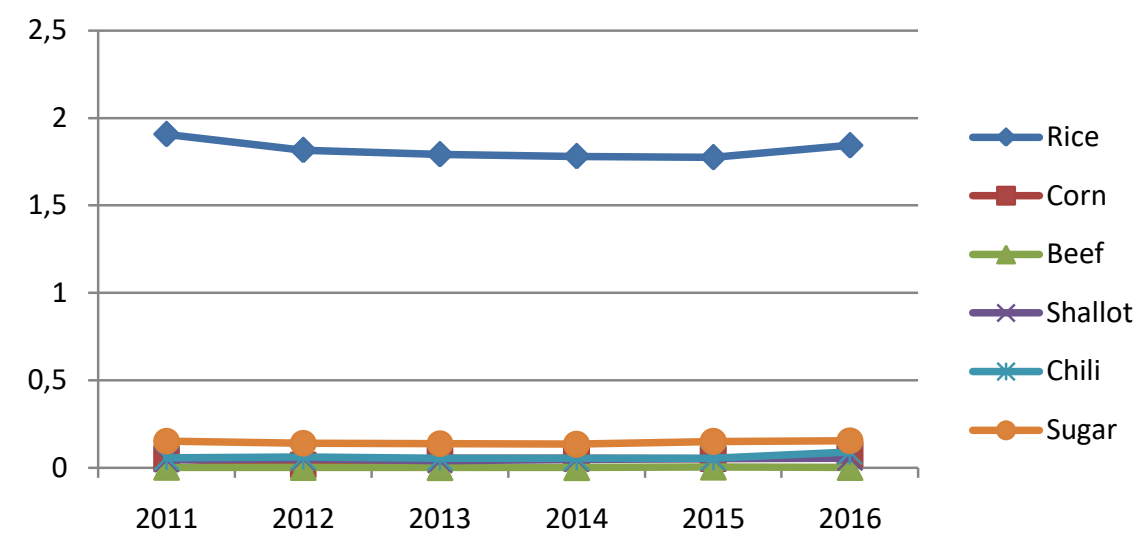

Figure 2 - Household Food Consumption in Rural, 2011-2016

Table 1 shows the amount of urban and rural household consumption for strategic food. The number of urban and rural household consumption always changes from year to year with insignificant changes. Changes in the pattern of household consumption of strategic food is influenced by several things, including: prices, income, and other social demographic factors. This is in accordance with the results of research conducted by (Widarjono, 2014).

Table 1 - Household Consumption of Strategic Food

\begin{tabular}{|c|c|c|c|c|c|c|}
\hline \multirow{2}{*}{ Strategic Food } & \multicolumn{6}{|c|}{ TAHUN } \\
\hline & 2011 & 2012 & 2013 & 2014 & 2015 & 2016 \\
\hline \multicolumn{7}{|c|}{ Urban } \\
\hline Rice & 1.523 & 1.528 & 1.487 & 1.466 & 1.477 & 1.504 \\
\hline Corn & 0.014 & 0.005 & 0.011 & 0.015 & 0.029 & 0.037 \\
\hline Beef & 0.012 & 0.011 & 0.008 & 0.008 & 0.015 & 0.013 \\
\hline Shallot & 0.045 & 0.053 & 0.039 & 0.047 & 0.054 & 0.053 \\
\hline Chili & 0.056 & 0.064 & 0.055 & 0.057 & 0.095 & 0.090 \\
\hline Sugar & 0.131 & 0.107 & 0.117 & 0.111 & 0.126 & 0.132 \\
\hline \multicolumn{7}{|c|}{ Rural } \\
\hline Rice & 1.907 & 1.816 & 1.792 & 1.781 & 1.775 & 1.843 \\
\hline Corn & 0.054 & 0.018 & 0.056 & 0.055 & 0.053 & 0.077 \\
\hline Beef & 0.004 & 0.003 & 0.002 & 0.002 & 0.005 & 0.003 \\
\hline Shallot & 0.046 & 0.053 & 0.041 & 0.048 & 0.052 & 0.055 \\
\hline Chili & 0.058 & 0.062 & 0.056 & 0.056 & 0.055 & 0.090 \\
\hline Sugar & 0.152 & 0.142 & 0.138 & 0.135 & 0.152 & 0.155 \\
\hline
\end{tabular}

Description: Amount of consumption in $\mathrm{kg}$.

Source: SUSENAS, 2011-2016.

The Pattern of Changes in Strategic Food Prices. The low diversification of food characterized by the dependence of rice consumption causes higher rice prices. This increase in rice price causes monthly inflation to be high and fluctuate.

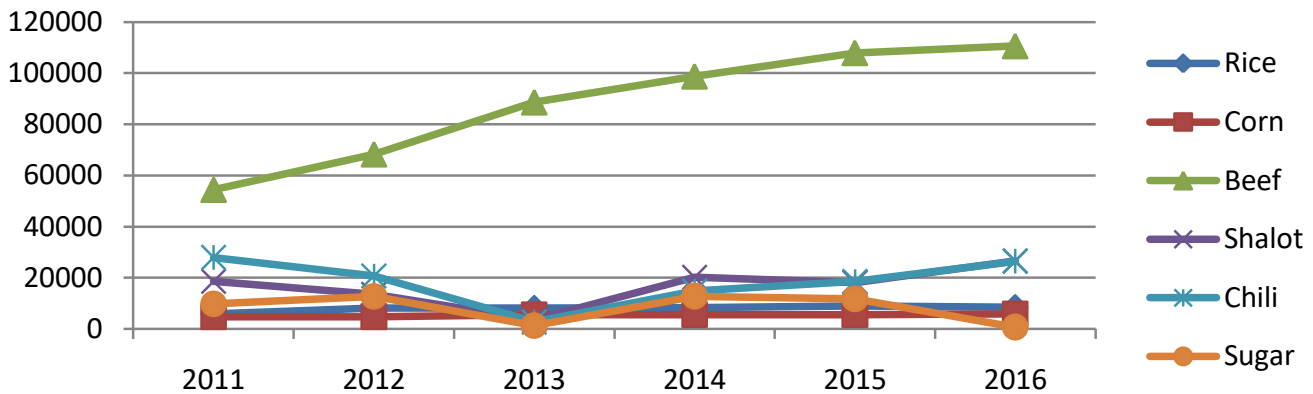

Figure 3 - The Pattern of Change in Food Price in Urban Year 2011-2016 (Source: SUSENAS, 2011-2016) 


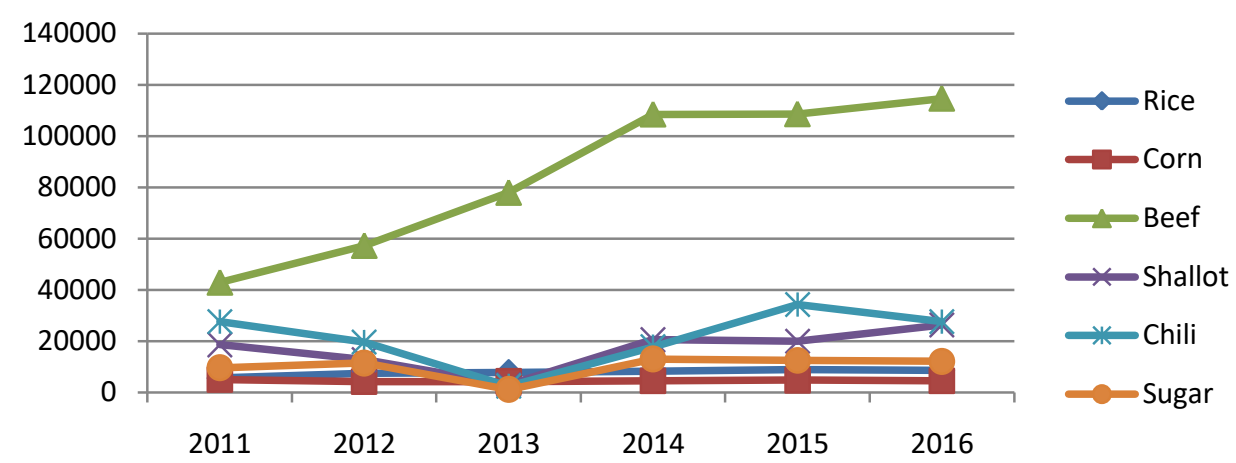

Figure 4 - The Pattern of Change in Food Price in Rural Year 2011-2016 (Source: SUSENAS, 2011-2016)

Figure 3 and 4 show that by 2013 all food items have increased. This food group contributed the most to inflation of 0.20 percent. Inflation in 2013 was the highest inflation rate since the 2008 crisis which reached 11.06 percent. This figure is an accumulation of previous inflation due to rising fuel prices.

Prices of shallot and chili (figures 3 and 4) both in urban and rural areas are very volatile between 2011-2016. Fluctuations in the price of chili and shallot are mostly due to the characteristics of the commodity. Chili, for example, is a perishable commodity and the presence or production of chilies and shallots is highly dependent on the season.

Share Household Food Expenditure. Consumer behavior can be known by looking at the proportion of consumer spending. The proportion of consumer spending for each food can illustrate the consumer's preference for consuming food.

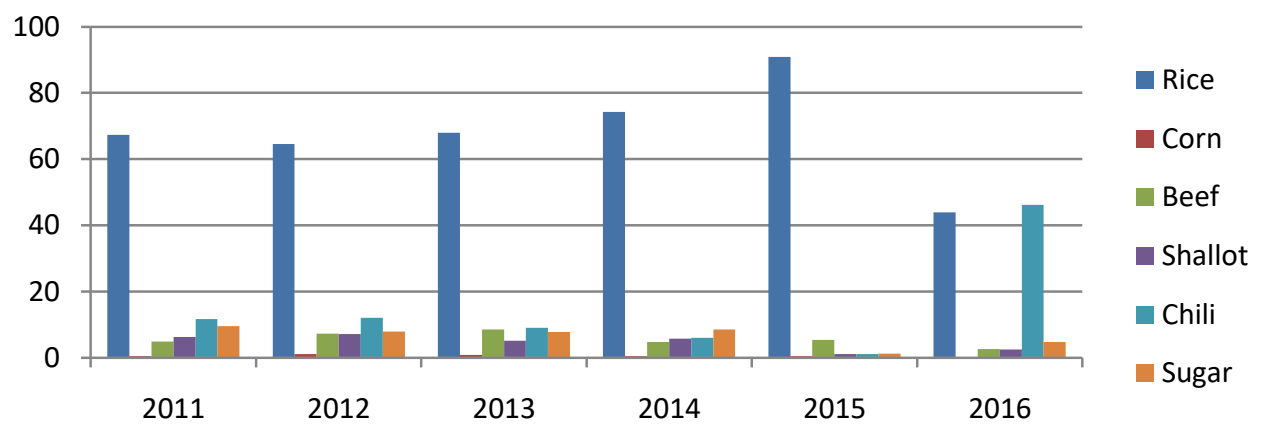

Figure 5 - The Pattern of Change in Food Price in Urban Year 2011-2016 (Source: SUSENAS, 2011-2016)

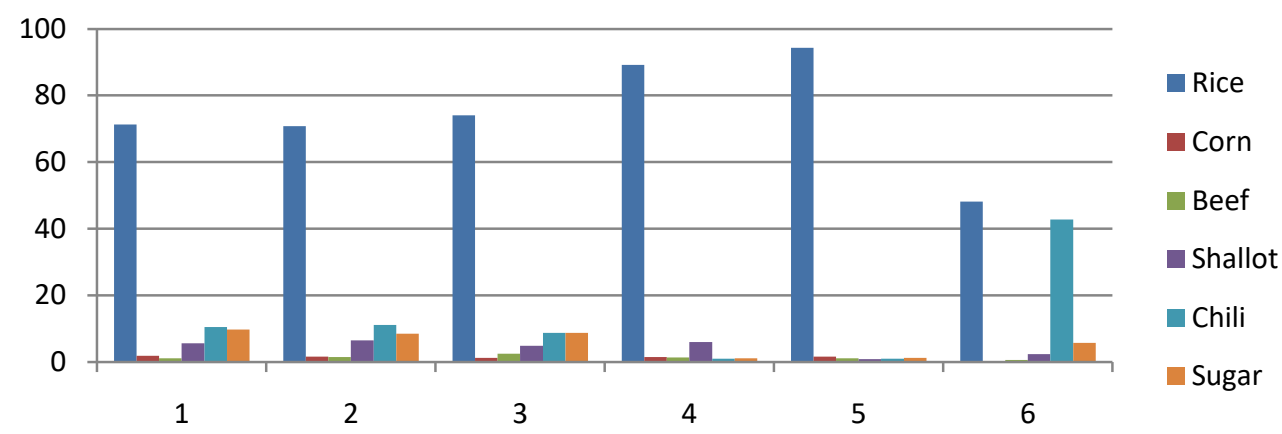

Figure 6 - The Pattern of Change in Food Price in Rural Year 2011-2016 (Source: SUSENAS, 2011-2016) 
Discussing the proportion of expenditure, there are two factors that must be considered, namely price and consumption. Both of these factors influence the proportion of expenditure. If the proportion of the expenditure of one type of food commodity is of great value, it can not be directly concluded that the consumption level of the food commodity is also large, but it must be observed also the amount of the price. So it can be seen which factors are more influential on the proportion of expenditure, whether the price factor or consumption. Therefore, to complement the discussion on the proportion of food commodity expenditure in Indonesia, it is also presented data on consumption and average food prices in Indonesia (Figure 1-4).

Figure 5 and Figure 6 show that both urban and rural households are dependent on rice consumption. In both urban and rural areas, the highest share of rice expenditure is in 2015 , which is $90.92 \%$ for urban areas and $94.29 \%$ for rural areas. This is caused by the increase in rice prices in 2015. From figure 3 and figure 4, it can be seen between the period of 2011-2015 the highest price of rice is in 2015.

\section{CONCLUSION}

The conclusions of this study are: (1) Between 2011-2016 the average consumption of rice in urban areas is smaller than in rural areas. Conversely, consumption of beef in urban areas is greater than in rural areas; (2) Chilli and shallot commodity prices are the most fluctuating commodities; (3) The largest proportion of household food expenditure in Indonesia is for rice commodities, both in urban and rural areas.

\section{ACKNOWLEDGEMENTS}

The authors would like to thank the central statistical agency for providing data. The study used secondary data in the form of raw data of SUSENAS (National Socioeconomic Survey) in 2011-2016. The SUSENAS data used included: total household expenditure, total household food expenditure, quantity and total strategic food expenditure (rice, corn, beef, shallots, chilies, and sugar), as well as the type of area where the household lives.

\section{REFERENCES}

1. Amang, B. 1995. National food policy. Publisher PT. Dharma Karsa Utama Jakarta.

2. Azis, B. 2011. Estimating Food Demand Elasticities in Pakistan: An Application of Almost Ideal Demand System. Forman Journal of Economic Studies. Vol. 7, 2011. Pp. 1-24.

3. National Development Planning Department. 2007. National Food and Nutrition Action Plan 2006-2010. Ministry of National Development Planning (BAPPENAS). Jakarta.

4. Jamal, E., 2007. Short-term Rice and Trap Interests. Agricultural Policy Analysis Vol.5, No.3, 2007. Indonesian Center for Agriculture Socio-Economic and Policy Studies.

5. Ogundari K. 2013. The Determinant of Food-Poverty State and the Demand for Dietery Diversity in Nigeria. Paper No. 1613022013 AAAE Fourth International Conference; 2013 Sep 22-25. Hammamet Tunisia. Tunisia (MA): African Association of Agriconomists.

6. Thiele S, Weis C. 2003. Consumer Demand for Food Diversity. Evidence for Germany. Food Policy 28 (2): 99-115.

7. Rachman, H.P.S. And Ariningsing, E. 2008. Strategies for Increasing Food Security of Household Food Prone. Agricultural Policy Analysis. 6 (3): 239-255.

8. Trisnowati, J., \& Budiwinarto, K. 2013. Price and Revenue Influence Review of Proportion of Household Food Expenditures (Complete Linear Approach Model).

9. Ugwumba COA, Effiong JAL. 2013. Analysis of Household Demand for Beef in Owerri Metropolis of Imo State, Nigeria. Journal of Chemical, Biological, and Physical Sciences. Vol 3 No. 2. Pp 1201-1205.

10. Ulubasoglu, M., 2010. Food demand elasticities in Australia. Deakin University.

11. Variant HR. 2006. Microeconomic Analysis 7th Ed. WW Norton \& Company. New York. 